\title{
Professionalization of management in sports vis-a-vis the liability of management board members for the obligations of a sports club
}

\author{
Jakub Kosowski ${ }^{1,2}$ \\ ${ }^{1}$ Faculty of Law and Administration, Maria Curie-Skłodowska University in Lublin, Poland \\ 2 Department of Sport, Lublin City Office, Poland
}

\section{abstract}

Background: The paper addresses one of the key issues relating to operations of sports entities, i.e. the liability for the obligations of the management board members. The aim is a comprehensive analysis of the legal basis of this subject, with abundant case-law in this matter taken into account.

Material and methods: The study is based on different criteria of the creation of the obligations of sports clubs, which entails a very high degree of complexity and multiplicity of legal rules relating to the problem in question. Taking these criteria into account, an analysis of the views presented by scholars in the field and the relevant case-law has been carried out. Practical problems in the application of the above regulations have also been identified.

Results: The results of the research lead to the conclusion that, in the light of the applicable legal regulations, the transfer of liability for the obligations of a sports club to the members of the board entails significant difficulties, especially when public-law obligations are concerned. In view of the above, the potential directions of action from public institutions were presented herein

Conclusions: As part of the conclusions, several options for systemic solutions were put forward, as the current legislation and the established case law of administrative courts do not allow public institutions to effectively pursue the fulfilment of obligations. In view of the above, in the author's opinion, it is necessary to amend the statutory provisions as put forward in the proposals de lege ferenda.

Key words: sports law, sport clubs, management, board member, local government unit, court decisions, case law.

\section{article details}

Article statistics: Word count: 5,431; Tables: 0; Figures: 0; References: 17

Received: March 2020; Accepted: June 2020; Published: December 2020

Full-text PDF: http://www.balticsportscience.com

Copyright ๑ Gdansk University of Physical Education and Sport, Poland

Indexation: Celdes, Clarivate Analytics Emerging Sources Citation Index (ESCI), CNKI Scholar (China National Knowledge Infrastructure), CNPIEC, De Gruyter - IBR (International Bibliography of Reviews of Scholarly Literature in the Humanities and Social Sciences), De Gruyter - IBZ (International Bibliography of Periodical Literature in the Humanities and Social Sciences), DOAJ, EBSCO - Central \& Eastern European Academic Source, EBSCO - SPORTDiscus, EBSCO Discovery Service, Google Scholar, Index Copernicus, J-Gate, Naviga (Softweco, Primo Central (ExLibris), ProQuest - Family Health, ProQuest - Health \& Medical Complete, ProQuest - Illustrata: Health Sciences, ProQuest - Nursing \& Allied Health Source, Summon (Serials Solutions/ProQuest, TDOne (TDNet), Ulrich's Periodicals Directory/ulrichsweb, WorldCat (OCLC)

Funding: This research received no specific grant from any funding agency in the public, commercial, or not-for-profit sectors. Author has declared that no competing interest exists.

Dr. Jakub Kosowski, tel. 605-519-040; e-mail: jakub.kosowski@lublin.eu

This is an open access article distributed under the terms of the Creative Commons Attribution-Non-Commercial-NoDerivatives 4.0 International (https://creativecommons.org/licenses/by-nc-nd/4.0/), which permits use, distribution and reproduction in any medium, provided the original work is properly cited, the use is non-commercial and is otherwise in compliance with the license. 


\section{INTRODUCTION}

Sports clubs in Poland are very peculiar entities in terms of economic transactions. Historically, one can notice a significant change in the structures of the functioning of sports clubs after 1989. The 1990s were the period of dynamic changes in the existence of individual sports branches. This concerns in particular, military, police (milicja), cooperative (the Start branch) or corporate sports clubs. This resulted in the bankruptcy and liquidation of a large group of entities. Some of them began operating under new socio-economic conditions, deprived, due to the process of municipalisation, of the assets they had used before. This also affected their organisational and financial situation.

The specificity of the activity of sports clubs, both historically and now, shows that a certain group of sporting entities have problems with the timely settlement of their obligations. Naturally, these obligations can be divided into two groups: private and public (taxes, social security contributions or other dues to public entities, e.g. adjudicated refunds of subsidies). It is not possible to discuss the aspect of the creation of liability, and thus the occurrence of effects in relation to the entity itself and to members of its management board without analysing the legal form in which the entity operates. The 1990s saw a large growth in newly registered entities operating as associations. A specific category of associations, namely physical culture associations, is also worth mentioning. This type of associations functioned under the Act of 3 July 1984 on physical culture (Journal of Laws 1984, No 34, item 181). As noted by H. Izdebski [1], physical culture associations operated on the principles set out in the Act on associations, but with changes resulting from the provisions of the Act on physical culture, these changes being extremely important as they referred to the administrative registration procedure and to the exercise of supervisory powers by administrative registration bodies. A specific category of associations are also student sports clubs currently operating on the basis of Article 4 of the Act of 25 June 2010 on sport (Journal of Laws 2010, No. 127, item 857), which are also based on the Law on Associations, but are registered with the locally competent district governor (starosta), and the Act sets out a catalogue of persons who may be members of such an association. Article 4 (3) refers to students, parents and teachers, but it should be noted that the quoted catalogue is of an open character [2]. Currently, many entities operate in the form of commercial law companies, which was forced by the statutory regulations on the functioning of professional leagues in various sports disciplines. These changes had a significant impact on the liability of management board members for the obligations due to different liability regimes introduced by the legislature, and depending on the legal form of operation of these entities. These issues will be thoroughly analysed further in this study.

\section{MATERIAL AND METHODS}

It is first necessary to list the types of obligations that may be assumed by sports clubs. Here the division into private-law and public-law obligations is of key significance. Within the first group of obligations, the following should be mentioned in particular: remuneration for the athletes and training staff, transport, accommodation, meals, fees for participation in competitions (referees' delegations, licences, etc.), training compensation/charges for transfers, organisation of sporting events. Of course, this is not an exhaustive list, because many other types of costs can be listed, but these costs listed herein constitute a very significant percentage of the sports club's budget. The evolution of commercial activities in the service sector caused that at present, enterprises, e.g. in the field of food and accommodation, are very reluctant to issue VAT invoices with short payment terms, often demanding advance payments. In addition, they avoid cooperation with entities with a low level of credibility, e.g. those with significantly outstanding amounts due. In their internal regulations, Polish sports associations and other sporting competition organisers 
reserve very precisely the moments of making settlements, e.g. for referee delegations or licences. In the practice of the functioning of professional leagues, one can also notice examples of mid-season verifications, which facilitates the collection of these dues under pain of suspension of the licence to the sports club, and thus the inability to participate in the competition. Practice shows that the lack of current liquidity negatively affects the settlement of obligations in relation to players and the training staff. In particular, this affects athletes who play smaller roles in the team, because usually top players are secured by their agents with a clause in the contract enabling the contract to be terminated due to the fault of the club when in default of payment of remuneration for a certain period (e.g. 30 days). Hence, recent years is the period of growth in arbitration within Polish sports associations. One of the first was the Basketball Arbitration Court at the Polish Basketball Association (now the Sports Arbitration Court at the Polish Basketball Association), and the number of cases heard per year (from a few to a dozen or so) shows that this is an efficient form of pursuing claims. In subsequent years, for example, the Hockey Arbitration Tribunal at the Polish Ice Hockey Federation was established, as well as the Arbitration Court at the Polish Handball Federation. Undoubtedly, the promptness of case settlement by arbitration is far more efficient than the settlement by common courts. It should also be noted that the courts of arbitration operating at Polish sports associations are a much cheaper solution, both for the plaintiff and the defendant (sports club), unlike international arbitration tribunals. A broader analysis of these issues, however, extends the scope of this study.

The second group of obligations are public-law obligations. These include, in particular, tax liabilities, social security contributions, or dues as a return of a misuses subsidy, or as a return of a subsidy taken in excess. It should be noted that so far, the first two types of obligations have played a key role in this group. Recent years, however, have shown a growing number of cases of sports clubs which, due to the auditing activities of public administration bodies, are subject to administrative proceedings in the field of reimbursement of a subsidy that was misused or taken in excess. In the event of a final administrative decision, this opens the way to enforcement proceedings, and where the enforcement proves to be ineffective - to transfer the liability to third parties, i.e. members of the management board.

Before proceeding to the analysis of the main subject matter hereof, i.e. the liability of management board members for the sports club's obligations, it is necessary to take a closer look at the available legal forms of conducting business activity in sport, since the principles of transferring the liability to third parties will depend on this element.

Practice shows that the most common legal form of a sports club is an association. In addition, more and more entities operate in the legal form of a foundation and although this is kind of a novelty, foundations, despite the lack of membership, can participate in competitions, have a club licence, etc. Sports clubs which play or played in the highest level of competition act in the form of commercial law companies. In accordance with Article 15 (3) of the Act on sport, a professional league in team games comprises only sports clubs operating as joint-stock companies or limited liability companies. It is worth noting at this point that in the original wording of the Act on sport, the possibility of operating in the form of a company was limited only to joint-stock companies. Limited liability companies were allowed to participate in professional leagues only since 12 September 2017 (Journal of Laws of 2017, item 1600).

Of course, the issue of liability for the obligations of the entity does not depend on the legal form in which the sports club operates. It is obvious that every legal person bears responsibility for its obligations. The liabilities are to be paid from the available funds, 
and if the sports club does not have such funds, it is possible to carry out the enforcement against movable and immovable property. Naturally, the question arises whether the sports club holds such assets. Practice shows that sports clubs having their own real estate are very rare. Most of these entities do not own real estate, while movable property is limited to office equipment and small sports equipment. In view of the above, a question arises as to the legal possibilities for the pursuit of claims where the management of an entity has led to a situation in which it cannot settle its obligations and the enforcement is ineffective. In accordance with Article 299 of the Commercial Companies Code of 15 September 2000 (consolidated text: Journal of Laws of 2019, item 505), if the enforcement against the company proves ineffective, the members of the management board shall be jointly and severally liable for its obligations. The literature states that this liability is of a personal, unlimited and joint-and-several nature, describing this scope of liability as very severe, but also pointed out the numerous exemptions introduced in Article 299 § 2 of the Commercial Companies Code [3]. Under that provision, a member of the management board may be relieved of the liability in question if he demonstrates that an application for bankruptcy has been filed in due time or at the same time an order has been issued to open restructuring proceedings or on the approval of a composition in the procedure for the approval of composition, or that the failure to file a petition for bankruptcy was not due to his fault, or that despite failure to file an application for bankruptcy or failure to issue a decision on opening the restructuring proceedings or failure to approve a composition in the procedure for the approval of composition, the creditor has not suffered any damage. In practice, a member of the management board has very broad possibilities to avoid liability, particularly in the context of filing for bankruptcy with a court [4,5]. The use of other opportunities seems unlikely due to the financial situation of such a sports club and the lack of prospects for generating revenue in the future. However, such precise regulations regarding the liability of board members for obligations are not included in the Act of 6 April 1984 on foundations (consolidated text: Journal of Laws of 2018, item 1491). By contrast, the Act of 7 April 1989, the Act on associations (consolidated text: Journal of Laws of 2019, item 713) until 20 May 2016 did not contain any regulation relating to the liability of management board members for the association's obligations. Following the amendment by the Act of 25 September 2015 (Journal of Laws of 2015, item 1923), very interesting regulations were introduced, but only for unincorporated associations. Until now, it was a very simplified form, with little practical importance [6]. The 2016 amendment introduced new opportunities for this category of entities. Although the unincorporated association does not have legal personality, but this entity was granted legal capacity, including capacity to be a party in court proceedings. They can also receive grants, for example for public benefit activities. By granting a large number of privileges, the legislature has also introduced significant restrictions. Pursuant to Article 40 (1b) of the Act on associations, each member shall be liable for the obligations of an unincorporated association without restriction with all its assets jointly and severally with other members and with the association. This liability arises once the enforcement against assets of an unincorporated association proves ineffective, although Article 40 (1) of the Act on associations states that Article 10(1b) does not prevent an action against a member of the management board before enforcement against assets of the unincorporated association proves ineffective [7, 8]. Therefore, a very broad liability was introduced and, interestingly, not only concerning the members of the board, but encompassing all the members of the association. It should be stressed that this is an important novelty, since until now a similar construction was not known to the Polish legislation.

Apart from general provisions, specific provisions should also be examined. Such regulations undoubtedly include the Act of 29 August 1997 the Tax Ordinance (consolidated text: Journal of Laws of 2019, item 900.). Article 116 of the Tax Ordinance provides that members of the management board are jointly and severally liable for outstanding tax 
dues of a limited liability company, a limited liability company in organisation, a jointstock company or a joint-stock company in organisation with all its assets, if enforcement against the company's assets has proved wholly or partly ineffective and the member of the management board:

1. failed to demonstrate that:

a) a petition for bankruptcy was filed in due time or restructuring proceedings were opened within the meaning of the Act of 15 May 2015 - Restructuring Law (Journal of Laws of 2019, items 243 and 326) or a composition was approved in the proceedings for approval of the composition referred to in the Act of 15 May 2015 - Restructuring law, or

b) the failure to file the petition for bankruptcy was without his fault;

2. does not indicate the company's assets, the enforcement against which will make it possible to cover the company's outstanding tax dues to a significant extent.

Therefore, in the analysed situation, we are dealing with a similar solution as provided for in Article 299 of the Commercial Companies Code, i.e. extensive inclusions. Moreover, the key regulations for members of companies' management boards are contained in Article $116 \S 2$ of the Tax Ordinance, which introduces temporal restrictions [9, 10]. The liability of management board members includes tax arrears on obligations whose due date expired while they were performing their duties as management board members, and arrears in respect of reimbursement of overpayment and payment of tax arising while performing their duties as management board members.

The Tax Ordinance also introduces detailed regulations related to entities other than commercial companies. Pursuant to Article 116a of the Tax Ordinance, members of the governing bodies of legal persons other than those listed in Article 116 are jointly and severally liable for tax arrears of these legal persons. This catalogue therefore includes sports clubs operating in the form of associations and foundations. The mutatis mutandis application of Article 116 of the Tax Ordinance in these cases leads to the conclusion that this liability is temporally limited, i.e. with regard to the period of holding office. Moreover, it is in the context of tax arrears that the legislature has regulated the situation between the establishment of an entity and its registration. Then, persons acting for the benefit of the association until the moment of registration are jointly and severally liable for such tax arrears. Thus, it may be the founding committee or the management board, as the establishment of the founding committee is not obligatory at present [7: 108-109].

The rules on liability of members of the management board of an unincorporated association look very interesting, and differently than in Article 40 Law on associations. A member of the management board of an unincorporated association is jointly and severally liable with the association and other members of the management board for the tax arrears of the association, and if the unincorporated association has no management board, the liability for the association's tax arrears is borne by a member of the association jointly and severally with the association and other members.

The Tax Ordinance in Article 2 §1(1) also makes it possible to hold members of the management board liable for non-tax receivables of the state budget and budgets of local government units. Non-tax budget receivables are understood as receivables that are not taxes and fees, constituting the revenue of the state budget or the budget of the local government unit resulting from public-law relations [9: 24-25, 11]. The catalogue of nontax budget receivables is contained in Article 60 of the Act of 27 August 2009 on public finance (consolidated text: Journal of Laws of 2019, item 869). Public funds constituting non-tax budget receivables of a public-law nature are the revenues of the state budget, 
the revenues of the budget of a local government unit, and in particular the amounts of subsidies to be reimbursed in the cases specified in this Act, i.e. misused or unduly received or received in excess (Article 169 and 252 of the Act on public finance) [12-14].

The last group of special provisions are the regulations of the Act of 13 October 1998 on the social insurance system (consolidated text: Journal of Laws of 2019, item 300). In accordance with Article 31 of the aforementioned Act, Article 116 and Article 116a of the Tax Ordinance shall apply mutatis mutandis to matters related to social security contributions [15]. Furthermore, the provisions on social security contributions shall apply mutatis mutandis, and therefore Article 116 and Article116a of the Tax Ordinance, to contributions to the Labour Fund, Solidarity Fund, Guaranteed Employee Benefits Fund and Bridging Pensions Fund, as well as to health insurance in terms of: their collection, enforcement, charging default interest and additional fee, penal provisions, establishing security on all real estate, movable property and the debtor's transferable rights, third party and heirs' liability, and the use of reliefs and remissions. Apart from tax arrears, this will be another very large group of obligations for which board members may be liable. From the practical viewpoint, it is important that the liability rules in all the three abovementioned groups of cases (tax arrears, non-tax budget receivables and social security contributions) are based on one act, i.e. the Tax Ordinance. This was also emphasized by the Supreme Court, which found, in the context of a social security case, the existence of joint and several liability arising just from the Tax Ordinance (judgement of the Supreme Court, Chamber of Labour, Social Security and Public Affairs, of 3 March 2011, II UK 307/10, Legalis No. 309846).

\section{DISCUSSION}

In view of the above analysis, it should be noted that the regulations on the liability of board members for the obligations of the sports club are contained in many legal provisions. Hence, one of the objectives of this study was a comprehensive research of the issue of liability options. The legal admissibility of holding the sports club management board members liable for the obligation of the sports club is one aspect of the problem in question. The second is to conduct a procedure which will allow the liability to be transferred to third parties. Pursuant to Article 108 of the Tax Ordinance, the third party's liability shall be decided by the tax authority. In the case of a local government unit, it will be its executive body, i.e. at the municipal level - the mayor (village mayor, town mayor, city president). This will determine the need for administrative proceedings, including the safeguarding for the party of all the rights under the Code of Administrative Procedure, i.e. the possibility of commenting on the evidence and materials collected and the requests made before the decision is taken [16]. Furthermore, it is necessary to note the possibility of appealing against the decision of the executive body of a local government unit to the local government board of appeal. The party will then be entitled to an action before the administrative court. This will undoubtedly affect the duration of the proceedings, but creates a significant risk on the part of the board member if the challenged decision is upheld, i.e. the increasing amount of default interest.

The conduct of administrative proceedings entails the obligation for the authority to demonstrate the ineffectiveness of enforcement. This condition of liability has been introduced by the provisions of the Code of Commercial Companies and the Tax Ordinance. The notion of ineffectiveness of enforcement means that undoubtedly there is no possibility of satisfying the claim under enforcement against any part of the sports club's assets. Therefore, the tax authority must demonstrate that the entity does not actually have assets that could be subject to effective enforcement (Judgement of the WSA in Olsztyn of 7 November 2007, case ref. no. I SA/OI 276/07, LEX No. 361345). The authority may establish it on the basis of any legally admissible evidence; moreover, the tax authority 
conducting the proceedings is required to take all measures to clarify the facts and to settle the case during the tax proceedings, including to comprehensively examine all the evidence (resolution of the Supreme Administrative Court in Warsaw of 8 December 2008, ref. no. II FPS 6/08, LEX No. 465091; judgement of the Supreme Administrative Court in Warsaw of 31 January 2006, ref. no. I FSK 554/05, LEX No. 219317). In practice, the question of demonstrating the ineffectiveness of enforcement against the assets of a sports club will not generate much difficulty, because, as I mentioned above, sports clubs usually do not own real estate and the catalogue of movable property is also substantially limited.

In the course of the administrative proceedings, a member of the management board of a sports club may indicate the existence of considerations excluding his responsibility, the so-called exoneration conditions [9: 578-579, 10: 623]. According to Article 116 of the Tax Ordinance, a member of the management board is not subject to this liability if he proves that: 1) a petition for bankruptcy has been filed in due time or restructuring proceedings have been commenced within the meaning of the Act of 15 May 2015 Restructuring Law (Journal of Laws of 2019 items 243 and 326) or a composition was approved in the proceedings for approval of a composition referred to in the Act of 15 May 2015 - Restructuring Law; 2) the failure to file for bankruptcy was not due to his fault; 3) specified the company's assets, the enforcement against which will allow him to satisfy the company's tax arrears in a substantial portion. In the practice of operation of sports clubs, the latter one is unlikely to be the case, while the first two are realistic, provided that the member of the management board has the relevant knowledge or uses a professional representative. It should be noted that the case law clearly specifies that the burden of presenting evidence which would indicate the existence of the conditions listed in Article 116 of the Tax Ordinance must be borne by the taxpayer (judgement of the Regional Administrative Court in Poznań of 23 January 2009, case ref. no. I SA/OI 1199/08, LEX No. 485879). A different attitude of a member of the management board not only does not allow him to be relieved from tax liability, but also makes it impossible for him to demonstrate one of the conditions for relieving from liability (judgement of the Regional Administrative Court in Warsaw of 19 February 2007, case ref. no. III SA/Wa 2406/06, LEX No. 322247). This means that the authority which runs the proceedings is not obliged to examine whether these conditions occurred, as it would significantly hinder the proceedings. In practice, I had an opportunity to conduct proceedings concerning the issues in question, and members of the management boards of sports clubs also pointed to other premises than those specified in Article 116 of the Tax Ordinance. It should be noted that the catalogue of conditions contained therein is closed [9: 578, 10: 623]. The pointing to health considerations or lack of actual involvement in the activities of the sports club is not legally permissible and does not affect the exclusion of liability. Unfortunately, especially the latter condition shows, the lack of sufficient legal a wareness of these persons, which under the current legislation generates a very high risk for the member of the management board, but also for his family in the context of liability with all of his assets, i.e. the common property.

\section{CONCLUSIONS}

In view of the above analysis, three general conclusions should be formulated, as part of which it is reasonable to put forward postulates for the law as it should stand (de lege ferenda). First of all, the liability of board members for the sports club's obligations depends on the legal form of the club. In this respect, it is worth stressing the important distinction in the area of liability for obligations between members of management boards of clubs operating in the form of commercial law companies (joint stock company, limited liability company) and board members of sports clubs operating in the form of associations and foundations. A certain novelty is the regulation of Article 40 (1b) of the Act on associations 
under which each member is liable for the obligations of an unincorporated association without restrictions with all its property jointly and severally with the other members and with the association. However, there is no similar regulation for associations. It should be emphasized that it is currently the form in which the vast majority of sports clubs operate, while the legal form of an unincorporated association is used sporadically. As part of the postulates de lege ferenda, it is undoubtedly necessary to point out the desirability of unification of these rules, in particular by introducing them in relation to associations as the most common legal form of sports clubs. It seems that the introduction of these principles will cause some reflection in management board members who are in no way involved in the ongoing activities of the sports club.

Secondly, different regimes of management board members' liability for sports club obligations apply under current legislation. One may notice the privileged position of public-law obligations over private-law ones. As regards associations for which there are no precise regulations as those contained in Article 299 of the Code of Commercial Companies, there is no effective possibility to hold members of the board liable for the obligations of a sports club other than public-law obligations. This undoubtedly affects the security of legal transactions. Of course, one can consider prosecution by way of criminal proceedings (e.g. in the area of fraud if the management board was aware of the club's situation and still signed subsequent commitments), or on the general principles of civil law, which, however, requires demonstrating, apart from the damage suffered, many other conditions [17]. In practice, however, I do not know any case of effective redress using the above-mentioned methods. Therefore, it should be postulated, as a proposal de lege ferenda, to enable holding liable for obligations other than public law the member of the board of the sports club operating as an association or foundation. It seems that this will affect the professionalization of sports club management in the context of the resignation of people who are not involved in the daily functioning of the sports club, and their role is limited to the occasional presence at the board meeting and signing the financial statements.

The third conclusion concerns the efficiency of the proceedings. It is obvious that, when conducting proceedings, it is necessary to safeguard the rights of a natural person, a management board member. In that regard, however, several factual situations must be mentioned. Concerning tax or social security arrears, conducting proceedings does not generate major problems and there is no significant risk of operation of statutes of limitation. In accordance with Article $118 \S 1$ of the Tax Ordinance, a decision on the tax liability of a third party may not be adopted if 5 years have elapsed from the end of the calendar year in which the tax arrears arose. The efficient conduct of enforcement proceedings and demonstrating the ineffectiveness of enforcement against the assets of the sports club opens the way for the initiation of proceedings and the issuance of the decision in question, which will already make the aforementioned provision inapplicable. The situation with regard to non-tax amounts due is different. The established case law indicates that, for non-tax dues, most often reimbursement of subsidies, the beginning of the statute-of-limitation period is interpreted adversely for public institutions. Article 118 $\S 1$ of the Tax Ordinance refers to the calendar year in which the tax arrears arose. The case-law states that, as regards subsidies, that moment is the transfer of the subsidy to the sports club's bank account, i.e. the moment at which it received and was to use the grant (see among others: judgement of the Supreme Administrative Court of 5 September 2018, I GSK 2583/18, Legalis No. 1869186; judgement of the Regional Administrative Court in Gdańsk of 16 May 2017, I SA/Gd 264/17, Legalis No. 1633066; judgement of the Regional Administrative Court in Lublin of 1 March 2019, I SA/Lu 776/18, Legalis No 1940415). One can hardly agree with these arguments. After all, the question of reimbursement of subsidies is being found after the task has been completed. It is therefore difficult to conclude that these arrears, thus the obligation to return the subsidy, arise at the time of 
the transfer of funds, i.e. before or at the beginning of the implementation of the public task. It is a matter of consideration whether it is the moment of submission of the report, but it seems that, from a functional point of view, such a moment is the moment when the administrative decision obliging to return the subsidy has become final. It was only then that the public institution is certain that it correctly decided on the reimbursement of the subsidy and that the sports club was informed that it had not rightfully questioned the actions of the public institution resulting from the audit of the performance of a public task. The adoption of such an argument makes it possible to conduct the proceedings to hold a member of the management board liable. With the current case-law, this possibility is illusory. This is due to a simple juxtaposition. Since the limitation period runs from the moment the subsidy is transferred to a sports club account, the following model chronology of events should be taken into account:

1. Implementation of the public task for the calendar year where the grant was transferred in the first month;

2. Submitting the report 30 days after the end of the task implementation and its audit. At this moment, the audits are carried out based on the audit plan and if there are no reasons for its faster implementation, assuming efficiently functioning public institutions, assuming that the completion of the audit with the issuance of the postaudit record will take another calendar year.

3. Failure to return the subsidy by the sports club results in the initiation of administrative proceedings to be concluded with an administrative decision. A decision issued e.g. by a local government unit may be appealed to the local government appeal board. An efficient conduct of the proceedings at this stage takes about half a year.

4. Further remedies against the administrative decision issued by the local government unit include an action to the regional administrative court, and then the possibility (where there are reasons to do so) of bringing a cassation appeal. This stage lasts from a year to a year and a half, provided, of course, that the sports club intends to use all its legal options available.

5. Once the decision on the return of the subsidy becomes final, the enforcement proceedings are initiated. A lot will depend on its efficiency and speed. However, the sports club may extend the enforcement proceedings by paying small amounts from time to time, and thus the authority will not be able demonstrating the ineffectiveness of the enforcement and initiate proceedings for the transfer of liability to third parties.

6. Failure to perform efficient enforcement or a deliberate action of the sports club aimed at extending the proceedings means that the local government unit may no longer have time or may have only a few months to conduct administrative proceedings with respect of transferring the liability to management board members. The activities from points 1 to 4 above take from about 3.5 to about 4 years. Thus, this means that enforcement proceedings should last a maximum of six months to successfully complete the whole administrative procedure by issuing a decision within five years. Unfortunately, this is highly improbable in practice.

Such a detailed analysis of this aspect of conducting proceedings by local government units was supposed to demonstrate that the adopted case-law was incorrect. Importantly, it negatively affects the finances of local government units, even despite the activity in transferring the liability to third parties. As a proposal de lege ferenda, the provisions of the Tax Ordinance should be urgently amended by distinguishing between limitation periods depending on the nature of the obligation concerned and specifying in detail the commencement of the limitation period for amounts due of non-tax nature. 


\section{REFERENCES}

[1] Izdebski H. Fundacje i stowarzyszenia [Foundations ans associations]. Warszawa; 1995, 98. Polish.

[2] Cajsel W. Ustawa o sporcie. Komentarz [Act on sports. Commentary]. Warszawa; 2011, 50-54. Polish.

[3] Siemiątkowski T. In: Sołtysiński S, editor. System Prawa Prywatnego, Tom 17A Prawo spółek kapitałowych [Private Law System, Volume 17A Capital companies law]. Warszawa; 2010, 634. Polish.

[4] Szczurowski T. In Jara Z, editor. Kodeks spółek handlowych. Komentarz [Commercial Companies Code. Commentary]. Warszawa; 2017, 1213-1218. Polish.

[5] Szajkowski A, Tarska M. In: Sołtysiński S, Szajkowski A, Szumański A, Szwaja J, eds. Kodeks spółek handlowych. Komentarz, tom II [Commercial Companies Code. Commentary, Volume II]. Warszawa; 2014, 954-956. Polish.

[6] Hadrowicz E. Stowarzyszenia zwykłe w polskim systemie prawnym [Ordinary associations in the Polish legal system]. Toruń; 2014, 88-174. Polish.

[7] Hadrowicz E. Prawo o stowarzyszeniach. Komentarz [Law on associations. Commentary]. Warszawa; 2016, 375376. Polish.

[8] Hadrowicz E. Odpowiedzialność członków za zobowiązania stowarzyszania zwykłego a podmiotowość prawna [Liability of members for obligations of an ordinary association and legal subjectivity]. Warszawa; 2019, 362-404. Polish.

[9] Mastalski R. In: Adamiak B, Borkowski J, Mastalski R, Zubrzycki J, eds. Ordynacja podatkowa, Komentarz [Tax Code. Commentary]. Wrocław; 2014, 577. Polish.

[10] Serwacki J. In: Dzwonkowski H, editor. Ordynacja podatkowa, Komentarz [Tax Code. Commentary]. Warszawa; 2014, 624. Polish.

[11] Nowak T, Dzwonkowski H. In: Dzwonkowski H, editor. Ordynacja podatkowa, Komentarz [Tax Code. Commentary]. Warszawa; 2014, 15. Polish.

[12] Walczak P. In: Walczak P, editor. Ustawa o finansach publicznych. Komentarz [Public Finance Act. Commentary]. Warszawa; 2017, 263-264. Polish.

[13] Misiąg W. In: Misiąg W, editor. Ustawa o finansach publicznych. Ustawa o odpowiedzialności za naruszenie dyscypliny finansów publicznych. Komentarz [Public Finance Act. Act on liability for violation of public finance discipline. Commentary]. Warszawa; 2019, 224-225. Polish.

[14] Kucia-Guściora B. In: Smoleń P, editor. Ustawa o finansach publicznych. Komentarz [Public Finance Act. Commentary]. Warszawa; 2014, 468. Polish.

[15] Strusińska-Żukowska J. In: Gudowska B, Strusińska- Żukowska J, editor. Ustawa o systemie ubezpieczeń społecznych. Komentarz [Act on the social insurance system. Commentary]. Warszawa; 2014, 589-608. Polish.

[16] Wróbel A. In: Wróbel A, Jaśkowska M, editor. Kodeks postępowania administracyjnego. Komentarz [Code of Administrative Procedure. Commentary]. Warszawa; 2013, 170-172. Polish.

[17] Banaszczyk Z. In: Pietrzykowski K, editor. Kodeks cywilny. Komentarz, tom I [Civil Code. Commentary]. Warszawa; 1999, 924-937. Polish. 